\title{
Metastatic calcification: Be watchful when renal failure complicates renal tubular acidosis
}

\author{
Manouri P Senanayake ${ }^{1}$, Sachith Gopeetha Mettananda ${ }^{2}$
}

Sri Lanka Journal of Child Health, 2012; 41(3): 148

(Key words: metastatic calcification; renal tubular acidosis; chronic renal failure)

\section{Case report}

A 14-year old boy, who attended clinic very irregularly for management of chronic kidney disease, developed tender localized multiple lumps over the left shoulder and elbow, without affection of joint movements. He was on sodium citrate and phosphate buffer for mixed renal tubular acidosis since the age of 3 years. Calcitriol, antihypertensives, iron and folic acid had been added when chronic renal failure developed. Widespread peri-articular soft tissue calcification was seen on radiography (Figure 1). Intracranial, pulmonary and renal calcifications were absent.



Figure 1: Extensive peri-articular soft tissue calcification around the left shoulder joint

Serum calcium was $7.44 \mathrm{mg} / \mathrm{dl}$ (Normal 8.4-10.4), serum phosphate $15.6 \mathrm{mg} / \mathrm{dl}$ (Normal 3.4-6.2), serum

${ }^{1}$ Professor in Paediatrics, Department of Paediatrics, Faculty of Medicine, University of Colombo, ${ }^{2}$ Lecturer in Paediatrics, Department of Paediatrics, Faculty of Medicine, University of Kelaniya

(Received on 26 September 2011: Accepted on 28 October 2011) creatinine $525 \mu \mathrm{mol} / \mathrm{l}$ (Normal <97) and serum parathyroid hormone 510ng/l (normal 15-65). [Calcium] x [Phosphate] was $116 \mathrm{mg}^{2} / \mathrm{dl}^{2}$. Phosphate buffer was discontinued, dietary phosphate restricted and calcium carbonate administered as a phosphate binder. Three days later, serum phosphate decreased to $8.6 \mathrm{mg} / \mathrm{dl}$, and serum calcium normalized. Pain and tenderness took four weeks to resolve.

\section{Discussion}

Phosphate buffer was prescribed for correction of hypophosphataemia caused by renal tubular acidosis. However, when phosphate excretion deteriorated due to impaired renal function, hyperphosphataemia resulted with secondary hyperparathyroidism contributing to this dyselectrolytaemia. [Calcium] $\mathrm{x}$ [Phosphate] product above $70 \mathrm{mg}^{2} / \mathrm{dl}^{2}$ is associated with a high risk of metastatic calcification in joints, soft tissue, kidney, brain, lung and arteries ${ }^{1-3}$. Our patient had only extensive soft tissue calcification but highlights the need for careful monitoring of serum calcium and phosphate levels especially when both tubular dysfunction and glomerulopathy co-exist.

\section{References}

1. Alfery AL. The role of abnormal phosphorus metabolism in the progression of chronic kidney disease and metastatic calcification. Kidney International 2004; 66:S13-7. http://dx.doi.org/10.1111/j.15231755.2004.09003.x

2. Bilge I, Sadikoğlu B, Emre S, et al. Brain calcification due to secondary hyperparathyroidism in a child with chronic renal failure. Turkish Journal of Pediatrics 2005; 47:287-90.

3. Tan O, Atik B, Kizilkaya A, et al. Extensive skin calcifications in an infant with chronic renal failure: metastatic calcinosis cutis. Pediatric Dermatology 2006; 23:235-8. http://dx.doi.org/10.1111/j.15251470.2006.0022 $\underline{4 . x}$ 